Meta

Journal des tradlucteurs

Translators' Journal

\title{
A Quebec-Canada Constitutional Law Lexicon (French to English)
}

\section{Wallace Schwab}

Volume 47, numéro 2, juin 2002

Traduction et terminologie juridiques

URI : https://id.erudit.org/iderudit/008015ar

DOI : https://doi.org/10.7202/008015ar

Aller au sommaire du numéro

Éditeur(s)

Les Presses de l'Université de Montréal

ISSN

0026-0452 (imprimé)

1492-1421 (numérique)

Découvrir la revue

Citer cet article

Schwab, W. (2002). A Quebec-Canada Constitutional Law Lexicon (French to English). Meta, 47(2), 279-280. https://doi.org/10.7202/008015ar d'utilisation que vous pouvez consulter en ligne.

https://apropos.erudit.org/fr/usagers/politique-dutilisation/ 


\title{
A Quebec-Canada Constitutional Law Lexicon (French to English)
}

\author{
WALLACE SCHWAB \\ Certified Translator and Terminologist, Ordre des traducteurs, \\ terminologues et interprètes agréés du Québec, Canada
}

\section{INTRODUCTION}

This past autumn (2001) the Québec government released a landmark French ${ }^{1}$ publication in the field of constitutional law; the English translation followed shortly thereafter. Québec's Positions on Constitutional and Intergovernmental Issues ${ }^{2}$ is an exhaustive cross-referenced compilation encompassing over 60 years of constitutional positions (from 1936 to March 2001) taken by the Québec government. The preparation of this study required extensive research in order to bring together many charters, statutes, policy papers, major ministerial speeches, draft legislation and correspondence on the subject from public and private collections. Throughout this entire process, the building blocks upon which this work rests are none other than the sum of the constitutional terminology used to express successive positions.

The lexicon-initially a computer-assisted translation tool for instant retrieval and accurate quoting-rapidly evolved into a small compendium of constitutionally relevant terms describing a host of Canadian and Québec realities. Please note that this is a synchronic snapshot of one set of subject-specific terms. In the following listing, the reader will find an edited version of the lexicon intended primarily as source material for terminologists and translators. Owing to the fact that this lexicon is Canadian and Québec oriented, plus the need for a semblance of terminological coherence over a sometime turbulent 60 -year period, these solutions are not necessarily adaptable to non-Canadian or non-Québec legal frameworks, places and times. As the reader will note, the lexicon is a bilingual set of monosemic pairs and its entries do not take into account synonyms and stylistic variations, which may otherwise be found in the 523 page study. No attempt is made to explain the chronological, conceptual or author-related subtleties found in the use of pairs such as "compétences: jurisdictions or powers," and "retrait: opting out or withdrawal," or the unusually prolific "clause dérogatoire" or "clause nonobstant": "override clause, derogation clause, notwithstanding clause, non obstante clause, or saving clause," plus many other fertile examples rich in pedagogical content for future studies. Nonetheless, anyone familiar with this field will note the presence of a few terms from another era, obviously owing to the fact that the lexicon spans 60 years, a sufficiently long period to see some terms enter the language while other have faded away. With few exceptions and to avoid confusion, commonplace translations involving cognates or calques have been left out of the listing. If some survived, this is mainly due to an unusual role they played in the study.

Lastly, this author must express appreciation and indebtedness to the constitutional specialists who graciously provided authoritative comments and source material 
to justify sometimes difficult choices between near-equivalent variants or to explain diachronical changes in usage. They prefer to remain anonymous. Ms. Janet Drury acted as a second reader and provided valuable comments and insights.

\section{NOTES}

1. Ministère du Conseil exécutif, Positions du Québec dans les domaines constitutionnel et intergouvernemental, Québec, Gouvernement du Québec, 2001, 543 p., ISBN 2-550-37798-2.

2. Ministère du Conseil exécutif, Québec's Positions on Constitutional and Intergovernmental Issues, Gouvernement du Québec, 2001, 523 p., ISBN 2-550-38325-7. 
Accord constitutionnel du 16 avril 1981

Accord constitutionnel du 5 novembre 1981

Accord de location fiscale de 1942

Accord du Lac Meech

Accord sur le commerce intérieur

Accord sur le libre-échange entre le Canada et les États-Unis

Acte de l'Amérique du Nord britannique

Acte de Québec

affirmation culturelle

affirmation du Québec

Agence canadienne des douanes et du revenu

aliments et drogues

allocations familiales

allocations scolaires

amicus curiæ

animation sociale

aspects financiers du fédéralisme

Assemblée nationale du Québec

assistance sociale

Association des universités et des collèges du Canada

assurance parentale

assurance-chômage

assurance-hospitalisation

assurance-maladie

asymétrie

asymétrique

autochtones

autodétermination

autonomie financière

autonomie gouvernementale

autorités fédérales

biculturalisme

cadre constitutionnel actuel

cadre visant à améliorer l'union sociale pour

les Canadiens

caractère unique

Chambre des communes

chambre fédérale

Charte canadienne des droits et libertés

Charte constitutionnelle de Victoria

Charte de la langue française.

Charte québécoise des droits et libertés

de la personne

chevauchement et dédoublement

citoyenneté

clause Canada

clause dérogatoire

Comité judiciaire du Conseil privé

Commission Bélanger-Campeau

Commission royale d'enquête sur les problèmes constitutionnels
Constitutional agreement, April 16, 1981

Constitutional agreement, November 5, 1981

Tax Rental Agreement, 1942

Meech Lake Accord

Agreement on Internal Trade

Canada-United States Free Trade Agreement

British North America Act

Québec Act

Cultural affirmation

Québec's affirmation

Canada Customs and Revenue Agency

food and drugs

family allowances

academic allowances

amicus curiae

social development

financial aspects of federalism

Québec National Assembly

social work

Association of Universities and Colleges of Canada

parental insurance

unemployment insurance

hospitalization insurance

health insurance

asymmetry

asymmetric

aboriginal nations / aboriginal peoples

self-government

financial independence

self-government

federal authorities

biculturalism

the current constitutional framework

Framework to Improve the Social Union for Canadians

uniqueness in character

House of Commons

federal house

Canadian Charter of Rights and Freedoms

Victoria Constitutional Charter, 1971

Charter of the French language.

Québec Charter of Human Rights and

Freedoms

overlapping and duplication

citizenship

Canada clause

override clause

Judicial Committee of the Privy Council

Bélanger-Campeau Commission

Royal Commission of Inquiry on

Constitutional Problems 
Commission sur l'avenir politique et constitutionnel du Québec commissions scolaires linguistiques communauté anglophone du Québec communauté internationale de langue française

communauté nationale distincte communauté québécoise d'expression anglaise communautés francophones et acadiennes du Canada

compensation fiscale ou financière compétence provinciale exclusive compétence sectorielle condition féminine conditions de travail conduite des relations intergouvernementales Confédération

Conférence fédérale-provinciale sur la Constitution, à Ottawa conférence fédérale-provinciale Conférence interprovinciale sur la Confédération de demain Conférence nationale des universités canadiennes Conférences de Charlottetown et de Québec confirmation de l'accession du Canada à l'indépendance

Conseil privé de la Reine pour le Canada

Conseil privé

Constituante

Constitution du Québec

Cour d'appel

Cour suprême du Canada

cours supérieures

création de la Cour suprême du Canada par le Parlement fédéral.

création du territoire du Nunavut par le Parlement fédéral.

décisions judiciaires en matière constitutionnelle

Déclaration de Calgary

décret

dédoublement

délégation de compétences

désengagement fédéral sur le plan financier

deux groupes ethniques fondateurs

développement de la petite enfance

développement économique régional

droit à l'autodétermination

droit civil

droit de retrait à l'égard d'une modification constitutionnelle

droit de retrait constitutionnel et compensation droit exclusif de propriété

droits civils
Commission on the Political and

Constitutional Future of Québec

linguistic school boards

English-speaking community

international community of French-Speaking peoples

distinct national community

Québec English-Speaking Community

French-Speaking and Acadian Communities of Canada

fiscal or financial compensation

exclusive provincial jurisdiction

sectorial jurisdiction

status of women

employment conditions

conducting intergovernmental relations

Confederation

federal-provincial Conference on

the Constitution, Ottawa

federal-Provincial Conference

Conference on the "Confederation of Tomorrow"

National Conference of Canadian Universities

Charlottetown and Québec Conferences

confirmation of Canada's accession to

independence

Queen's Privy Council for Canada

Privy Council

Constituent Assembly

Constitution of Québec

Court of Appeal

Supreme Court of Canada

superior courts

creation of the Supreme Court of Canada by

the federal Parliament.

creation of the Nunavut territory by

the federal Parliament.

court decisions on constitutional affairs

Calgary Declaration

order-in-Council

duplication

delegation of powers

federal financial disengagement

two founding ethnic groups

early childhood development

regional economic development

right to self-determination

civil law

opting-out right from a constitutional amendment

constitutional right of opting-out compensation

exclusive ownership

civil rights 
droits collectifs

droits consacrés

droits et libertés de la personne

droits individuels et linguistiques

droits linguistiques

éducation des adultes

égalité des provinces

emploi et main-d'œuvre

énoncé de politique

enseignement dans la langue de la minorité

enseignement postsecondaire

Entente de Charlottetown

Entente-cadre Canada-Québec sur l'habitation sociale

Entente-cadre sur l'union sociale

ententes administratives

ententes de réciprocité

entrée de Terre-Neuve dans la fédération canadienne.

équilibre entre pouvoirs et ressources financières équipement de services publics locaux

espace économique commun

famille et enfance

fédération efficace

fonction publique

Fondation canadienne des bourses d'études du millénaire

Fondation canadienne pour l'innovation

formation de la main-d'œuvre

formation professionnelle

forum constitutionnel

forums intergouvernementaux

Francophonie internationale

fronts communs des provinces

garantie pour les minorités

garderies

gestion des cours d'eau

gestion du milieu

Golfe du Saint-Laurent

gouvernements autonomes autochtones

Gouverneur général

identité nationale

identité québécoise

impôt foncier

impôt québécois sur le revenu.

impôt sur le revenu

impôt sur les dons

impôt sur les successions

Imprimeur de la Reine

Imprimeur du Roi

intégrité du territoire du Québec

intégrité territoriale

intérêts économiques collective rights

established rights

human rights and freedoms

individual and language rights

language rights

adult education

equality of provinces

employment and labour

policy statement

education in the language of the minority

post-secondary education

Charlottetown Accord

Canada-Quebec Global Agreement on Social

Housing

Social Union Framework Agreement

administrative agreements

reciprocity agreements

entry of Newfoundland into the Canadian

federation.

balance between powers and financial resources

local public service facilities

common economic space

family and childhood

efficient federation

public service

Canada Millennium Scholarship Foundation

Canada Foundation for Innovation

labour training

vocational training

the constitutional forum

intergovernmental forums

Francophonie

joint actions by provinces

guarantee for minorities

nurseries and day-care centres

management of waterways

environmental management

Gulf of St. Lawrence

self-governing aboriginal governments

Governor general

national identity

Québec's identity

property tax

Québec income tax

income tax

gift tax

estate tax and succession duty

Queen's Printer

King's Printer

Québec's territorial integrity

territorial integrity

economic interests 
juste part des dépenses fédérales

justice pénale pour les adolescents

législatures provinciales

l'entente sur l'union sociale

les allocations familiales

les sphères d'activités provinciales

liberté et sécurité nationales

Lieutenant-gouverneur

Loi constitutionnelle de 1982

Loi pour améliorer les pensions des vieillards

et des aveugles

Loi sur la consultation populaire

Loi sur la langue officielle

Loi sur l'avenir du Québec

loisirs

mariage et divorce

mécanismes intergouvernementaux

mise au point des projets de modification

constitutionnelle

mobilité de la main-d'œuvre

modification constitutionnelle sur les pensions de vieillesse

multiplication des échanges entre les pays

nations autochtones

nécessité de pouvoirs fiscaux provinciaux clairs

nécessité du consentement des parties

contractantes

nécessité d'un veto pour le Québec

nécessité d'une nouvelle répartition

des ressources financières

négociations constitutionnelles

normes et objectifs pancanadiens

Organisation mondiale du commerce

organisations et forums internationaux

organismes fédéraux de communications

pacte entre deux peuples

pacte fédératif

paix, ordre et bon gouvernement

partage des compétences

partage des ressources financières

partenaires dans le cadre de la

souveraineté-association

partenariat économique et politique

partenariat, développement, actions

patrimoine historique et culturel

patrimoine naturel

perception fiscale

péréquation

peuples fondateurs

placement de la main-d'œuvre

plateau continental

points d'impôt

politique de conjoncture fair share of federal expenditures

Criminal justice for young persons

provincial legislatures

Social Union Framework Agreement

family allowances

areas of provincial jurisdictions

national freedom and security

Lieutenant governor

Constitution Act, 1982

Act to improve pensions for the aged and

the blind

Referendum Act

Official Language Act

Act respecting the future of Quebec

leisure activities

marriage and divorce

intergovernmental machinery

developing projects for constitutional amendment

labour mobility

constitutional amendment regarding old-age pensions

multiplication of exchanges between countries

aboriginal nations

need for clear provincial fiscal powers

need for consent on the part of contracting parties

need for a veto for Quebec

need for a new distribution of financial resources

constitutional negotiations

Canada-wide standards and objectives ${ }^{* * *}$

World Trade Organization

organizations and international forums

federal communications agencies

pact between two peoples

federative pact

peace, order and good government

distribution of powers

distribution of financial resources

partners within the framework of

Sovereignty-Association

economic and political partnership

partnership, development, achievement

historic and cultural heritage

natural heritage

tax collection

equalization payments

founding peoples

manpower placement

continental shelf

tax points

cyclical policies 
Politique du Québec

politique familiale

politique industrielle

politique intergouvernementale

politique maritime nationale

politiques économiques

pouvoir accessoire

pouvoir de dépenser

pouvoir déclaratoire

pouvoir d'emprunt

pouvoir résiduaire

pouvoirs de réserve et de désaveu

pouvoirs exceptionnels

pouvoirs fédéraux exceptionnels

pouvoirs indéfiniment extensibles

pouvoirs unilatéraux

préambule constitutionnel

prestation nationale pour enfants

prêts et bourses aux étudiants

procédure bilatérale

procédure civile

procédure de l'unanimité

procédure de modification constitutionnelle

procédure générale

processus de réforme constitutionnelle

professions et métiers

programme de garantie de recettes fiscales

programme fédéral d'après-guerre

programmes cofinancés

Projet d'accord constitutionnel

Projet de loi fédéral sur la réforme

constitutionnelle

projet de souvraineté-association

projet d'union des colonies britanniques

d'Amérique du Nord.

proposition Fulton-Favreau

propositions du gouvernement du Québec

propositions fédérales visant le renouvellement

de la fédération

propriété du domaine public

propriété provinciale

propriété publique

protection constitutionnelle des droits et

libertés de la personne

protection des consommateurs

proximité des besoins et intérêts locaux

question référendaire

radio et télévision

radio-télévision éducative

rapatriement de la Constitution canadienne

rapport de la commission Bélanger-Campeau

recensements et statistiques

recherche universitaire
Quebec's policy

family policy

industrial policy

intergovernmental policy

national marine policy

economic policies

ancillary power

spending power

declaratory power

borrowing power

residuary power

powers of reservation and disallowance

emergency powers

exceptional federal powers

infinitely extensible powers

unilateral powers

constitutional preamble

national child benefit

student loans and bursaries

bilateral procedure

civil procedure

unanimous procedure

constitutional amending procedure

general procedure

constitutional reform process

professions and trades

program for guaranteeing tax revenues

federal post-war years program

shared-cost programs

Draft Agreement on the Constitution

Federal bill on constitutional reform

Sovereignty-Association proposal

project to unite the British colonies of North

America.

Fulton-Favreau Formula

proposals by the government of Québec

federal proposals aimed at renewing the

federation, September 1991

ownership of the public domain

provincial property

public ownership

constitutional protection of human rights and

freedoms

consumer protection

proximity of local needs and interests

referendum question

radio and television

educational radio-television

patriation of the Canadian Constitution

Bélanger-Campeau Commission's report

census and statistics

university research 
Référendum québécois sur le projet de souveraineté-association relance des discussions constitutionnelles relations de travail relations intergouvernementales relations internationales renseignements personnels renvoi fédéral devant la Cour suprême du Canada

renvoi relatif à la sécession du Québec résolution unanime de l'Assemblée nationale du Québec

retrait et compensation fiscale ou financière

rôle du Québec et de son gouvernement sans le consentement du Québec santé et services sociaux

Secrétariat des conférences intergouvernementales canadiennes (SCIC)

sécurité culturelle

sécurité du revenu

sécurité sociale

services correctionnels

services sociaux

seuil de majorité

situation démographique au Canada

Société canadienne d'hypothèques et de logement (SCHL)

société distincte souveraineté provinciale souveraineté-association spécificité du Québec spécificité, particularisme stabilisation des revenus provinciaux statut de la langue française Statut de Westminster Statut du Québec statut et pouvoirs particuliers pour le Québec statut particulier subsides et transferts fédéraux subventions fédérales

Système de justice pénale pour les adolescents tarif douanier

taxation directe

taxe provinciale d'éducation universitaire taxes à la consommation

transport aérien

transport ferroviaire

transport ferroviaire, maritime et aérien transport maritime

transport routier

transports

travaux et ouvrages
Québec referendum on the Sovereignty-

Association project

new round of constitutional discussions

labour relations

intergovernmental relations

international relations

personal information

federal reference to the Supreme Court of

Canada

Reference on the Secession of Québec

unanimous resolution of the Québec National

Assembly

opting-out with fiscal or financial compensation

role of Québec and its government

without the consent of Québec

health and social services

Canadian Intergovernmental Conferences

Secretariat (CICS)

cultural security

income security

social security

correctional services

social services

majority threshold

demographic situation in Canada

Canada Mortgage and Housing Corporation

(CMHC)

distinct society

provincial sovereignty

Sovereignty-Association

Québec's specificity

specificity, sense of identity

stabilization of provincial revenues

status of the French language

Statute of Westminster

Québec's status

status and specific powers for Quebec

special status

federal subsidies and transfers

federal subsidies

Criminal justice system for young persons

customs tariffs

direct taxation

provincial university educational tax

consumption tax

air transport

railway transport

railway, maritime and air transport

sea transport

road transport

transportation

works and undertakings 
tribunal constitutionnel

tribunaux de juridictions civile et criminelle

tribunaux familiaux

tribunaux fédéraux

Union canadienne

union sociale

unitarisme

unité canadienne

universités et enseignement postsecondaire

urbanisme

valeurs mobilières

vice-premier ministre constitutional court

courts of civil and criminal jurisdictions

family courts

federal courts

Canadian union

social union

unitarianism

Canadian unity

universities and post-secondary education

city and town planning

securities

Deputy Prime Minister

Very long entries involving titles of laws, projects, reports and court referrals:

Avis de la Cour suprême du Canada dans le Renvoi concernant la Constitution du Canada

Opinion of the Supreme Court of Canada in the Reference concerning the Constitution of Canada

Avis de la Cour suprême du Canada dans le renvoi fédéral relatif à la sécession du Québec Opinion of the Supreme Court of Canada in the federal Reference on the Secession of Québec

Avis de la Cour suprême du Canada dans le Renvoi relatif à un projet de résolution concernant la Constitution du Canada

Opinion of the Supreme Court of Canada in the Reference for a draft resolution concerning the Constitution of Canada

Création du territoire du Yukon par le Parlement fédéral dans un champ de compétence provinciale

Creation of the Yukon Territory by the federal Parliament in a field of provincial jurisdiction

Déclaration de Balfour sur le statut des dominions de l'Empire britannique.

The Balfour Declaration on the status of the Dominions of the British Empire

Loi sur le processus de détermination de l'avenir politique et constitutionnel du Québec Act respecting the process for determining the political and constitutional future of Québec

Loi donnant effet à l'exigence de clarté formulée par la Cour suprême du Canada dans son avis sur le Renvoi sur la sécession du Québec

Act to give effect to the requirement for clarity as set out in the opinion of the Supreme

Court of Canada in the Quebec Secession Reference

Loi instituant la Commission sur l'avenir politique et constitutionnel du Québec

Act to establish the Commission on the Political and Constitutional Future of Québec

Loi instituant une commission royale d'enquête sur les problèmes constitutionnels

Act to institute a royal commission of inquiry on constitutional problems

Loi modifiant la Loi sur le processus de détermination de l'avenir politique et constitutionnel du Québec

Act to amend the Act respecting the process of determining the political and constitutional future of Québec

Loi sur l'exercice des droits fondamentaux et des prérogatives du peuple québécois et de l'État du Québec

Act respecting the exercise of the fundamental rights and prerogatives of the Québec People and the Québec State 
Modification bilatérale de l'article de la Loi constitutionnelle permettant la mise en place, au Québec, de commissions scolaires linguistiques

Bilateral amendment of the section of the Constitution Act, thereafter making it possible to establish linguistic school boards in Québec

Modification constitutionnelle sur les pensions de vieillesse et prestations additionnelles Constitutional amendment regarding old-age pensions and additional benefits.

Projet fédéral de rapatriement unilatéral de la Constitution canadienne accompagné de modifications constitutionnelles substantielles.

Federal project for the unilateral patriation of the Canadian Constitution along with substantial constitutional amendments.

Rapport de la Commission royale d'enquête sur les problèmes constitutionnels (commission Tremblay, Québec)

Report of the Royal Commission of Inquiry on Constitutional Problems (Tremblay Commission, Québec)

Rapport de la Commission royale sur les relations entre le Dominion et les provinces (la

Commission Rowell-Sirois)

Report of the Royal Commission on Dominion-Provincial Relations (the Rowell-Sirois Commission)

Rapport de la Commission sur l'avenir politique et constitutionnel du Québec (commission Bélanger-Campeau, Québec)

Report by the Commission on the Political and Constitutional Future of Québec (BélangerCampeau Commission, Québec)

Rapport du Groupe de travail sur l'unité canadienne (la Commission Pépin-Robarts, fédéral) Report of the Task Force on Canadian unity (Pépin-Robarts Commission, federal)

Rapport préliminaire de la Commission royale d'enquête sur le bilinguisme et le biculturalisme (commission Laurendeau-Dunton, fédéral)

Preliminary Report of the Royal Commission on Bilingualism and Biculturalism (LaurendeauDunton Commission, federal)

Référendum au Québec sur le projet de loi sur l'avenir du Québec prévoyant l'accession du Québec à la souveraineté ainsi qu'une offre de partenariat économique et politique avec le Canada Referendum in Québec on the Bill respecting the future of Québec providing for Québec's accession to sovereignty as well as an offer of economic and political partnership with Canada 